\title{
Entrepreneurial Education, Sustainability and Youth Employment*
}

\author{
Miriam Cresta**
}

\begin{abstract}
For the future socio-economic development of member States, European policy makers urge endowing youngsters with an entrepreneurial mindset through business education starting from school. Such investments in education would activate a virtuous circle that enables overcoming the miss-match between supply and demand through effective education, reducing the number of early school leavers through the introduction of more practice-oriented teaching methods, increasing youth employment and nurturing a vocation for social innovation at the local level.
\end{abstract}

Keywords: Entrepreneurial Mindset; Innovative Teaching; Entrepreneurs and Start-Uppers; Digital Platforms; Multi-Stakeholder; Youth Employment; Local Economic and Social Development; Global Markets

\section{Entrepreneurship and Education}

Entrepreneurship education has been at the centre of European policies for the last ten years and is considered a key factor of sustainability to reduce youth unemployment and the skills gap, disseminate social and economic innovation, and facilitate the development of a new society where young people can become active participants in building their future. In the Entrepreneurship 2020 Action Plan, the European Commission invites member States to ensure they "Offer the opportunity to young people to have at least one practical entrepreneurial experience before leaving compulsory education" by assigning the central role of flywheel and driver to the education sector and national school systems in collaboration with the system of institutions, companies, not-for-profit and employers' organizations.

In the 2014 Amway Italia survey, 64\% of respondents considered that entrepreneurship can be taught (global average 63\%). Of the same opinion are $70 \%$ of under $35 \mathrm{~s}$ (global average $70 \%$ ) while $29 \%$ of Italians in school consider chambers of commerce and non-profit organizations $(35 \%)$ as optimal teaching environments. Introducing entrepreneurship education into the Italian education system is a challenge entailing cultural constraints starting from the terminology used to transmit its inherent potential. A more appropriate term to contextualize

\footnotetext{
* Invited Article

** CEO, Junior Achievement Italia (miriam.cresta@jaitalia.org)
} 
these policies in our country would be "enterprisingness" to encompass the "key competence" aspect. From an educational perspective, it is relatively easy to confuse an entrepreneurial education program with a traditional business management course, which is entirely different and not centred on promoting creativity, innovation and self-employment.

The recent "La Buona Scuola" education policy intends to activate a national digital education plan introducing favourable conditions for the development of entrepreneurial education in schools. The Italian education and training reform recognizes as a priority the educational objectives of enhancing knowledge in legal, economic and financial matters and self-entrepreneurship education, inviting the experimentation of creativity and entrepreneurship through alternating school and work, and the use of innovation laboratories.

Acquiring this key competence is not only a must for young people choosing the entrepreneurship path per se, but is and will be the case for all future employees or self-employed workers. An entrepreneurial mindset grants students the opportunity to reflect on the personality components and traits required to make informed choices and learn to develop flexibility from an early age.

"This does not mean that schools should anticipate the tasks and competences that the labour market will require, but to lay the foundations so these skills can begin to be developed. Schools must equip themselves to provide environments that can promote skills that enable young people to face the challenges that an increasingly globalized world presents, activating educational activities that help youngsters in choosing to be proactive in relation to their professional future by activating employability skills. A body of evidence demonstrates that the development of employability skills in higher education is conducive to future employment success (Harvey 2005)."1

While the recent Eurydice report Entrepreneurship Education at School states that there is no specific national strategy for entrepreneurship education in Italy, some established and proven training practices for the acquisition of this key competence already exist in secondary school.

\section{Junior Achievement Italia}

The non-profit organization Junior Achievement Italia $^{2}$ in its Impresa in Azione (Enterprise in Action) program adopts the "mini-company"3 teaching tool that has been used for over 25 years in Great Britain and for over a decade in Nordic countries.

"The student company is a pedagogical tool based on practical experience by means of running a complete enterprise project, and on interaction with the external environment."4

In 2015, the Impresa in Azione program was adopted by 235 schools and 672 classes involving over 13,000 Italian students aged 16 to 18 . Over 4,000 students are taking the various exams to obtain certification for the entrepreneurial skills acquired at school, a real pass for the future thanks to the Entrepreneurial Skills Pass platform ${ }^{5}$. 
Higher education institutions can also freely activate this program in the schoolwork alternation and foresees building a real company of students - from the creation of the idea to its production and sale - through the acquisition of entrepreneurial skills in the broadest sense. Students develop real economic activities and manage their own companies, albeit in a protected environment and for pedagogical purposes. The program lasts 100 hours and is part of a class coordinated by at least one teacher on a specific subject.

The educational objectives of the program include:

- Understanding the idea creation process

- $\quad$ Providing knowledge of entrepreneurial management models

- Increasing student proactivity and local knowledge

- $\quad$ Enhancing individual and collective creativity

The viability of the program is ensured by the coordinating teacher and the dream coach, an entrepreneur, start-upper or manager trained by Junior Achievement who supports, directs and inspires the students' projects.

The teacher attends the 6-hour Teacherprenuer workshop and provides innovative teaching activities based on an experiential and practical approach enabled by the use of the digital platform (www.impresainazione.it) and a learning environment that combines real experiences with appropriate educational content, following the program's road map and establishing relations with other Italian and European colleagues. Thus far, 550 entrepreneurial education teachers have been trained and the Fermi Institute of Pontedera, one of the schools running this program for over a decade, was awarded The Entrepreneurial School Award by the European Parliament along with 10 institutions in other countries.

The dream coach can be a manager from one of the companies supporting the Association or a local entrepreneur often coming from the world of small and medium-sized enterprises or a social enterprise, a young start-upper or selfemployed person. This is followed by an e-learning training course that enables them to support a mini-company.

The introduction of entrepreneurship learning tools transforms traditional teaching methods, pushing teachers to reformulate formal learning occasions and spaces into informal ones. They facilitate the inclusion and active participation of the school population more inclined to experiential paths, introducing students to the real world while reinforcing the importance of investing in education, encouraging schools to enable new partnerships not only with traditional partners from the business world, but also with all those initiatives - digital gyms, Fablab, incubators - that in recent years have expanded the ecosystem of stakeholders in entrepreneurial education school projects.

\section{Conclusions}

In short, entrepreneurship education is in every way a disruptive education model. Youngster involved in a business education program at school can acquire numerous transferable skills. The European Council, in dictating the priorities of the Europe $2020^{6}$ strategy, asserts: 
"In addition to basic skills such as literacy and numeracy, entrepreneurship requires the gradual development of a range of competences, starting from an early age. These include, for instance, creativity and a sense of initiative; problem solving and critical thinking; decision-making and risk taking; adaptability and perseverance; self-discipline and a sense of responsibility; leadership and teamwork; planning and organizational ability; understanding of the social, economic and cultural context; and language skills and the ability to persuade."

These skills have for several years been at the centre of the discussions and research of the Danish Foundation for Entrepreneurship that defined the common European framework to which to ascribe an entrepreneurship education path (ASTEE - Assessment Tools and Indicators for Entrepreneurship Education).

Figure 1: Entrepreneurial Skills

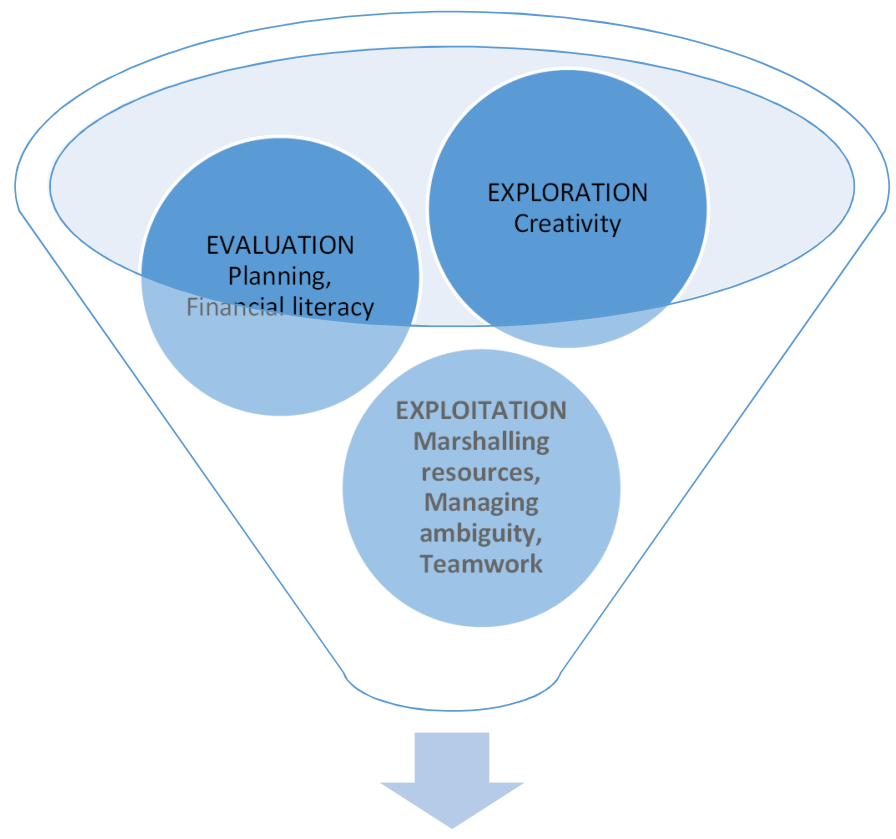

ENTREPENEURIAL MINDSET

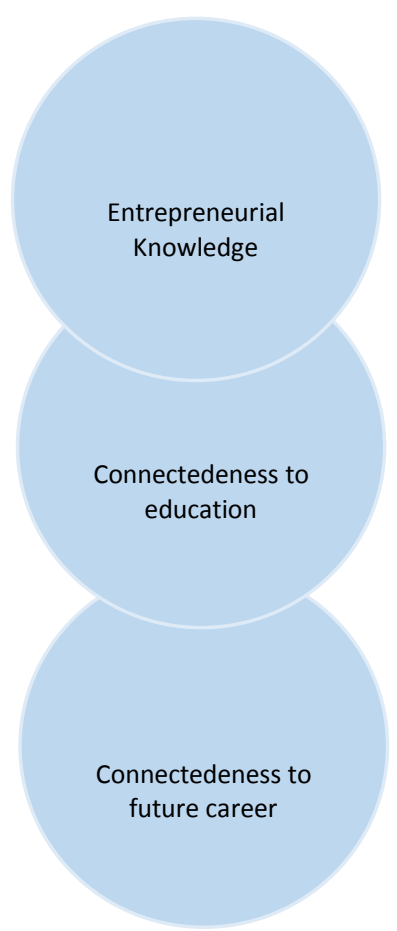

Core self-evalutation: General self-efficacy, Locus of control, Self-esteem

This approach is evident in the research results of Marta Consolini conducted by IPSOS for Junior Achievement Italy in 2015, where in most cases (60\%), young people exposed to an entrepreneurial education program are aware of the value of their tenacity ("I keep trying until I find the solution to a problem") or in $41 \%$ of cases claiming to be "the first to suggest a new solution to a problem" or even "seeing opportunities where others see problems" in $37 \%$ of cases.

Finally, some initial assessments of the social and economic impact of investments in entrepreneurship education have shown positive results. In Canada, it is estimated that each year $\$ 425$ million of the national economy can be directly attributed to the entrepreneurial activities undertaken by former students. The 
European experience in Britain shows that those who encountered entrepreneurship at school have a higher rate of employment, better wages, higher propensity to start-ups and capacity to create more jobs in companies generating more profit and choosing the most innovative sectors ${ }^{7}$.

Important in today's increasingly liquid socio-economic environment are educational activities that develop the employability potential of individuals that even when not directly related to increased employment will still ensure the development of specific adaptive strategies.

\section{Bibliography}

Arora, A., Fosfuri, A., \& Gambardella, A. (2001). Markets for technology and their implications for corporate strategy. Industrial and Corporate Change, 10(2), 419-451. http://dx.doi/10.1093/icc/10.2.419

Arrigo, E. (2009). Market-Driven Management, Global Competition and Corporate Responsibility, Symphonya. Emerging Issues in Management (symphonya.unimib.it), 1, 54-70

http://dx.doi.org/10.4468/2009.1.06arrigo

Brondoni, S. M. (2014). Global Capitalism and Sustainable Growth. From Global Products to Network Globalisation, Symphonya. Emerging Issues in Management (symphonya.unimib.it), 1, $10-31$

http://dx.doi.org/10.4468/2014.1.02brondoni

Brondoni, S. M. (2008). Market-Driven Management, Competitive Space and Global Networks, Symphonya. Emerging Issues in Management (symphonya.unimib.it), 1, 14-27

http://dx.doi.org/10.4468/2008.1.02brondoni

Carroll, A. B., \& Buchholtz, A. K. (2014). Business and society: Ethics, sustainability, and stakeholder management. Nelson Education.

Elmuti, D., Khoury, G., \& Omran, O. (2012). Does entrepreneurship education have a role in developing entrepreneurial skills and ventures'effectiveness?. Journal of Entrepreneurship Education, 15, 83.

Fayolle, A., \& Gailly, B. (2015). The impact of entrepreneurship education on entrepreneurial attitudes and intention: Hysteresis and persistence. Journal of Small Business Management, 53(1), 75-93.

Kuratko, D. F. (2005). The emergence of entrepreneurship education: Development, trends, and challenges, Entrepreneurship theory and practice 29.5, 577-598.

Lans, T., Blok, V., \& Wesselink, R. (2014). Learning apart and together: towards an integrated competence framework for sustainable entrepreneurship in higher education. Journal of Cleaner Production, 62, 37-47.

Neck, H. M., and Greene, P.G. (2011). Entrepreneurship education: known worlds and new frontiers, Journal of Small Business Management 49.1, 55-70.

Salvioni, D. M., Astori, R. (2013). Sustainable Development and Global Responsibility in Corporate Governance, Symphonya. Emerging Issues in Management (symphonya.unimib.it), 1, 28-52

http://dx.doi.org/10.4468/2013.1.03salvioni.astori 


\section{Notes}

${ }^{1}$ Promuovere competenze di imprenditorialità e di occupazione per creare sviluppo, cosa può fare la scuola [Promoting entrepreneurship and skills development to create employment, what schools can do], Maria Assunta Zanetti, COR - Centro Orientamento Università di Pavia.

${ }^{2}$ On the experiment conducted in the field of entrepreneurship education, see the recent ISFOL insights at http://www.isfol.it/osservatorio-isfol/osservatorio-isfol/osservatorio-isfol/osservatorioisfol-4-2015/articolo-la-settima-competenza-chiave

3 This tool has also been adopted by four Italian institutions for $50 \%$ of their 4 th year school population in the European ICEE project - Innovation Cluster for Entrepreneurship Education - led in Italy by MIUR - Direzione ordinamenti scolastici (Ministry of Education - School system directorate).

4 European Commission, Enterprise and Industry DG, September 2005 "Mini-Companies in Secondary Education".

${ }^{5}$ http://entrepreneurialskillspass.eu/about.html

${ }^{6}$ EU Official Journal, the Council Conclusions on entrepreneurship in education and training (2015/C 17/02)

${ }^{7}$ Source: A compilation of evidence on the impact of entrepreneurship education strategies and measures, European Commission, January 2015 